Article

\title{
The Development of the Articles in Castilian: A Functional Approach
}

\author{
Christopher J. Pountain
}

School of Languages, Linguistics and Film, Queen Mary, University of London, London E1 4NS, UK; c.j.pountain@qmul.ac.uk

Received: 14 March 2019; Accepted: 20 March 2019; Published: 28 March 2019

\begin{abstract}
The development of the definite and indefinite articles in Castilian may be regarded as an instance of capitalization or adfunctionalization, following partial exaptation of the Latin demonstrative ille, which involves progressive widening without significant loss of function, the rendering of overt distinctions which were previously covert through the contrast between definite article, indefinite article and the "zero" determiner, the creation of new expressive possibilities and the facilitating of further distinctions in the grammatical system in combination with other determiners (usage with possessives, demonstratives and tal is examined).
\end{abstract}

Keywords: refunctionalization; Castilian articles; definiteness; adfunctionalization; indefiniteness

\section{Introduction}

For several years, I have been investigating examples of a historical linguistic phenomenon, which in Pountain (2000a) I called capitalization, in which a linguistic element with one or more existing functions appears to be progressively exploited to acquire ever more functions. In the history of Castilian, I have studied the extension of the copular verb estar (Pountain 2000a), the reflexive (Pountain 2000b, 2000c, 2008) and the creation of the neo-neuter article lo (Pountain 2015). Without going into detailed summaries of these studies, I begin by calling attention to what may be considered the most salient characteristics of these three developments.

First, they involve a widening, without significant loss, of function, in the course of which the creation of a structural opposition is critical. Estar appears to invade the functional field of ser, while maintaining its original locative function, but although ser to a certain extent yields ground to estar, it could not be said that ser loses any of its own functionality, but rather that there is progressive competition between the two verbs. The same can be said of the reflexive, which does not cease to express literal reflexivity, even though it competes with the "etymological" passive voice (ser + past participle), which comes to have a reduced frequency and stylistic range. The most that can be said, therefore, in these cases, is that there is a change of markedness in the element which is drawn into such competition. The case of $l o$ is somewhat different, since the neuter gender as a morphological category disappeared completely in Castilian and the masculine definite article, which lo might have supplied (cf. several varieties of Catalan (Badía Margarit 1951, p. 287)) took the form el; the origin of this change might be seen as exaptation in the sense of Lass (1990) or refunctionalization in the sense of Smith (2011), according to which an element which is obsolescent comes to be used with a new value not necessarily related to its original value, which disappears. However, once lo is established as a determiner for an adjective, it thereafter broadens its functions without further loss.

Secondly, capitalization usually makes overt a distinction that was previously covert. The opposition between ser and estar with a past participle distinguishes a dynamic passive voice (La puerta es cerrada "the door is (being) closed/is (regularly) closed") from a stative passive voice (La puerta está cerrada "the door is (in a state of having been) closed"). The use of the reflexive as a passive voice 
allows the discrimination of a "middle" voice which does not envisage the participation of an agent. The reflexive passive La puerta se cerró "the door closed" in fact does not allow the statement of an agent at all: *La puerta se cerró por Miguel "the door was closed by Miguel" is unacceptable, and to express an agent Spanish uses the etymological passive La puerta fue cerrada por Miguel (unless, as is more frequent in speech, the passive is avoided altogether). The neo-neuter article (always appearing with an adjective, never with a noun) refers either to an absolute concept (lo referido $=($ todo) lo referido "(all) that has been referred to") or to a partitive concept (lo alto = la parte alta "the high part") by contrast with the nominal reference of an adjective used with other determiners (so el enfermo "the sick person", un joven "a young person").

Thirdly, capitalization creates new expressive possibilities. The extension of the opposition between ser and estar to adjectival complements has given rise to what are usually termed "subjective" uses of estar + adjective (so the "objective" Juan es amable "Juan is kind, a kind person" contrasts with Juan estuvo más amable que de costumbre "Juan was being kinder, behaving in a kinder way, than usual"). The reflexive has extended to both transitive and intransitive verbs, producing contrasts in meaning with the non-reflexive which are extremely difficult to describe because they are idiosyncratic to the verbs concerned, although there is no denying the reality of the distinction (such contrasts were studied in detail by (Moreira Rodríguez and Butt 1996)). Lo has developed a value of "extreme degree" which gives it what appears to be an adverbial function, there being no agreement between $l o$ and the adjective, which is normally required within a noun phrase, e.g., No sabes lo hermosa que es "You don't know how beautiful she is".

Fourthly, the consequences of capitalization may have a wider impact on the grammatical system. The establishment of the opposition between ser and estar with adjectives appears to have given rise to a parallel distinction in inceptive verbs (verbs of becoming): ponerse is restricted to contexts in which estar is permitted, so ponerse is used with triste (Juan se puso triste "Juan became sad" corresponds to Juan está triste "Juan is sad") while hacerse is used with viejo (mi padre se hizo viejo "my father became old" corresponds to mi padre es viejo "my father is old"). The favoring of the reflexive as a middle voice may have led to the lower frequency of the etymological passive as well as to the eventual demise of a potential competitor, the incipient indefinite pronoun hombre, which was amply attested in Old Castilian, and the comparative success of which can be observed in its French cognate on. The "extreme degree" function of lo competes with the older cuán deriving from Latin quam and finally overtakes it, since it is used not only with adjectives but with adverbs and whole noun phrases: Todos elogian lo gran actor que es "Everyone praises how great an actor he is" (Álvarez Menéndez 1970, p. 348), Me sorprende lo en su punto que está la sopa "It surprises me how absolutely ready the soup is" (Gutiérrez Rexach 1999, p. 44).

To a certain extent, capitalization corresponds to Smith (2011) notion of adfunctionalization. However, what is distinctive about capitalization is that it comprises a whole series of adfunctionalizations which are usually carried out over a considerable period of time. Thus, capitalization appears to correspond closely to the phenomenon described by Sapir within the venerable tradition (if not always completely honorable: see Pountain 2008) of the "genius" of a language:

All languages evince a curious instinct for the development of one or more particular grammatical processes at the expense of others, tending always to lose sight of any explicit functional value that the process may have had in the first instance, delighting, it would seem, in the sheer play of its means of expression. (Sapir 1921, p. 60)

This in turn recalls Voltaire's (Voltaire 1879) definition of génie de la langue: "son aptitude à dire de la manière la plus courte et la plus harmonieuse ce que les autres langages expriment moins heureusement" ("its capacity for saying in the shortest and most harmonious way what other languages express less felicitously"). The results of the cases of capitalization I have described so far may indeed be viewed as characteristic of Spanish and consequently a part of what might be called its "genius". They are accordingly features which non-native speakers are always very conscious, since they are the 
most problematic areas in learning and teaching the language, as well as in translation (as is apparent in many of the examples in this article).

\section{The Articles of Castilian}

The creation of the Castilian articles and their subsequent development seem to constitute another prima facie case of capitalization. Their growing frequency century by century is shown by the raw figures in Table 1:

Table 1. Raw occurrences and frequency per million words of the definite and indefinite articles in the Corpus del español (Davies 2002-2019) ${ }^{1}$.

\begin{tabular}{|c|r|r|r|r|}
\hline & el/la $\mathrm{N}$ & un/una $\mathrm{N}$ & los/las $\mathrm{N}$ & unos/unas $\mathrm{N}$ \\
\hline \multirow{2}{*}{$1200 \mathrm{~s}$} & 171,304 & 7702 & 85,752 & 518 \\
& $(25,508)$ & $(1147)$ & $(12,769)$ & $(77)$ \\
\hline \multirow{2}{*}{$1300 \mathrm{~s}$} & 69,593 & 714 & 28,521 & 30 \\
& $(26,069)$ & $(267)$ & $(10,684)$ & $(11)$ \\
\hline \multirow{2}{*}{$1400 \mathrm{~s}$} & 201,374 & 3992 & 86,532 & 118 \\
& $(24,674)$ & $(489)$ & $(10,603)$ & $(14)$ \\
\hline \multirow{2}{*}{$1500 \mathrm{~s}$} & 566,151 & 93,243 & 269,380 & 6362 \\
& $(33,236)$ & $(5474)$ & $(15,814)$ & $(373)$ \\
\hline \multirow{2}{*}{$1600 \mathrm{~s}$} & 445,108 & 83,587 & 167,940 & 3910 \\
& $(36,046)$ & $(6769)$ & $(13,600)$ & $(317)$ \\
\hline \multirow{2}{*}{$1700 \mathrm{~s}$} & 397,277 & 64,501 & 207,240 & 3149 \\
& $(40,470)$ & $(6571)$ & $(21,111)$ & $(321)$ \\
\hline \multirow{2}{*}{$1800 \mathrm{~s}$} & 885,140 & 226,731 & 361,058 & 5265 \\
& $(45,869)$ & $(11,749)$ & $(18,710)$ & $(273)$ \\
\hline \multirow{2}{*}{$1900 \mathrm{~s}$} & 975,746 & 300,905 & 395,102 & 9107 \\
& $(42,754)$ & $(13,185)$ & $(17,312)$ & $(399)$ \\
\hline
\end{tabular}

\subsection{Widening of Functions}

The articles have been the object of many valuable studies which I have no intention of replicating and on the results of which I am drawing; I pass immediately to a schematic chronology of their functions (Table 2). It can be seen that for each article there is a constant widening of function (adfunctionalization), against the background of a clear opposition between definite and indefinite article, although we must also take into account that the absence of a determiner (which I denote by $\varnothing$ in the examples) continues to be a possibility and also forms part of this functional contrast. Thus, two of the characteristics of capitalization identified in Section 1 are present.

Table 2. Functional extension of the Castilian articles (based chiefly on Company Concepción 1991, Garachana Camarero 2009 and Ortiz Ciscomani 2009).

\begin{tabular}{|c|c|c|}
\hline & Definite Article (ILLE) & Indefinite Article (UNUS) \\
\hline Latin & demonstrative: necessarily deictic (anaphoric) & number \\
\hline "Late" Latin & $\begin{array}{l}\text { anaphoric: not necessarily deictic definite } \\
\text { (attenuated demonstrative) }\end{array}$ & \\
\hline "Early" Castilian & extended anaphoric & \\
\hline 13th Cent. & $\begin{array}{l}\text { generic (subject human-referring nouns; unique } \\
\text { reference entities nominalizer }\end{array}$ & $\begin{array}{l}\text { "introductory": referential, specific (generic) } \\
\text { (plural unos/unas: see Table 5) }\end{array}$ \\
\hline 14th Cent. & extension of generic value & \\
\hline 15th Cent. & $\begin{array}{l}\text { abstract nouns } \\
\text { mass nouns }\end{array}$ & $\begin{array}{l}\text { not necessarily specific } \\
\text { "metaphorical" uses }\end{array}$ \\
\hline 16th Cent. & extension of nominalizing use & $\begin{array}{l}\text { proper nouns } \\
\text { unique reference entities } \\
\text { infinitives } \\
\text { extension of the plural }\end{array}$ \\
\hline
\end{tabular}

1 The reason for using the Corpus del español for this study is that, in spite of the many errors it contains, it has the enormous advantage of allowing searches by part of speech; without this facility, however rudimentary, obtaining statistics of this type would have been a practical impossibility. From the statistics in Table 1, it can be seen that: (a) the indefinite article always lags behind the definite article in terms of relative frequency; (b) the significant advance of the indefinite article takes place in the 16th century; and (c) the formal indefinite plural unos/unas is comparatively infrequent. 
We now look more closely at the development of these functions.

\subsubsection{The Definite Article}

The generally accepted explanation of the evolution of the Romance definite article (see, for example, Harris 1978, pp. 70-72) suggests that it begins with what may be considered an exaptation or partial refunctionalization of one of the Latin demonstratives (most widely ille), in conjunction with its substitution as a demonstrative by a reinforced form ( ${ }^{*}$ accu ille in the case of Castilian). The impression we have of the use of ille in Late Latin (especially in the Peregrinatio Egeriae, for which the data are well known) is of a change of markedness, evidence for which is its greater frequency. The starting point for the extension of functions which is characteristic of capitalization is its anaphoric value, and it is in an "extended" anaphoricity that we can find the key to its subsequent expansion. ${ }^{2}$ Its use with unique reference entities ( $e l$ sol "sun", el rey "king", etc.) may be seen as a cultural anaphoricity (it would be inappropriate to speak of $e l$ rey "the king" in a community in which there was no king, or in which there was more than one king). Inalienable possession (typically with parts of the body) may also be considered a type of anaphoricity, in which the possessed element (la mano "hand" in (1a), el pie "foot" in (1b)) is necessarily associated with either the subject of the verb (1a) or with an indirect object (1b) (Juan):

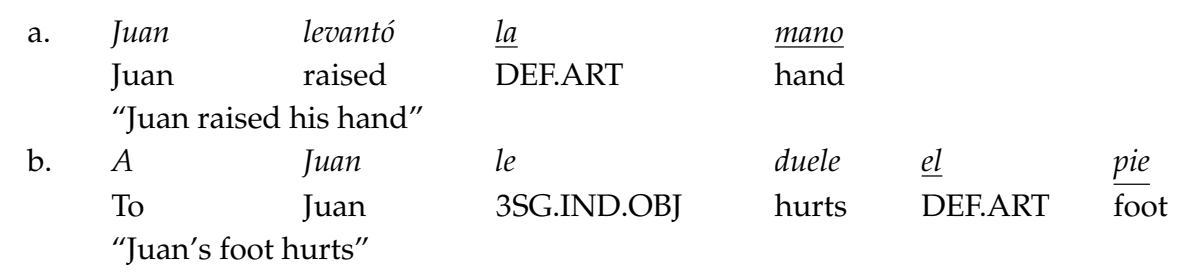

It is also interesting, incidentally, that the notion of what is "inalienable" seems to have undergone greater extension in Castilian than in some other Romance languages: Butt and Benjamin (2013, p. 29) pointed out that, while a sentence such as (2) is usual in Castilian, it has no parallel in French, for example.

(2) $\mathrm{Te}$

$\begin{array}{llll}\text { Te } & \text { he aparcado } & \frac{\text { el }}{\text { coche }} \\ \text { 2SG.OBJ I have parked } & \text { DEF.ART } & \text { car } \\ \text { "I have parked your car" } & & \end{array}$

What may be regarded as the strict function of definiteness was probably associated with the use of the demonstrative with the antecedent of a defining relative clause, a modern Castilian example of which is given in (3): there are numerous examples of such a function in Late Latin (4).

(3)

$\begin{array}{llllll}\underline{E l} \text { un } & \begin{array}{l}\text { hombre } \\ \text { sombrero }\end{array} & \text { que confundió } & \text { su } & \text { mujer } & \text { con } \\ \text { DEF.ART man } \quad \text { REL confused } & \text { OBJ } & \text { his } & \text { wife } & \text { with } \\ \text { a } & & & & \\ \text { "The man who mistook his wife for a hat" } & & & & \end{array}$

(4) Et quoniam nobis iter sic erat, ut per valle illa media qua tenditur per longum, iremus [...]

(Peregrinatio Egeriae, 43,4)

"And since our way was such that we went through the/that middle valley which stretched out ahead $[\ldots] "$

2 For what may be regarded as a pragmatically oriented account of such a change in markedness between deixis and anaphora related to the emergence of the Romance definite article, see Kabatek (2012, pp. 82-83). 
This function is in fact closely related to that of anaphoricity, since anaphoricity may be construed as presupposing an understood defining relative clause such as "which we have already mentioned". Indeed, it can be seen that in (4) the demonstrative fulfils both of these functions simultaneously: illa appears with the antecedent (valle) of a relative clause (qua tenditur per longum), but this noun has been previously mentioned in the discourse and so the reference is also anaphoric.

The definite function also includes nouns that are defined by adjectives (5a) or adjectival phrases (5b), which can be considered as reduced relatives.

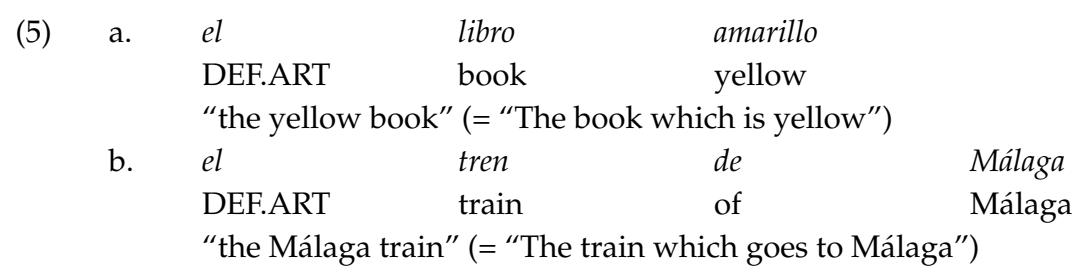

The use of the definite article to indicate the problematic notion of genericness must be considered separately. Genericness is almost certainly also related pragmatically to anaphoricity since it depends on shared cultural knowledge of what can constitute a class (or, rather, the totality of a class). Nonetheless, the notions are different. With nouns pragmatically understandable as denoting a generic concept, there is potential ambiguity between a generic and anaphoric reference of the definite article in Castilian, which only the discourse context will resolve: in Me gusta el vino, el vino could be understood as wither anaphoric ("the wine", the wine already mentioned) or generic ("wine", wine in general) (see Butt and Benjamin 2013, p. 31): I reached similar conclusions concerning the multiple values of the reflexive in Pountain (2000c). Genericness can be expressed by both the plural (6a) and, less freely (see Chesterman 1991, pp. 32-39), by the singular (6b), although the latter usage is actually attested as early as the 13th century (6c):

(6) a. Los ingleses [PL.] tienen fama de ser muy flemáticos

b. El cuclillo [SG.] pone sus huevos en nidos ajenos

"The cuckoo lays its eggs in other birds' nests"

c. [...] mas cruel \& mas dannoso que es el lobo [SG.] en la grey de las oueias en la noche. (CdE:

Alfonso X, Estoria de España I, S.XIII)

"[...] more cruel and damaging than is the wolf in the flock of sheep at night"

We may also regard the use of the definite article with abstract nouns (la vergüenza "shame", la belleza "beauty") and mass nouns (la leche "milk", el hielo "ice") as essentially generic, since these nouns denote general concepts. As can be seen in Table 2, the generic values of the definite article appear after its anaphoric values; generally speaking, it is in these various generic values that the Romance definite article and the English definite article do not correspond (the only point in common is the generic use of the singular (6b) and (6c), which is in fact the first such usage to be attested with any regularity).

The development of these essentially pragmatic functions is perhaps the most significant factor in the process of capitalization or adfunctionalization of ILLE. However, ILLE also came to have a range of nominalizing functions (Company Concepción 1991, p. 418): it is used with adjectives (7a), infinitives (7b) and, rather later, with clausal complements (7c) (the first such example I have found in CdE is from the 16th century $(7 d))$ : 


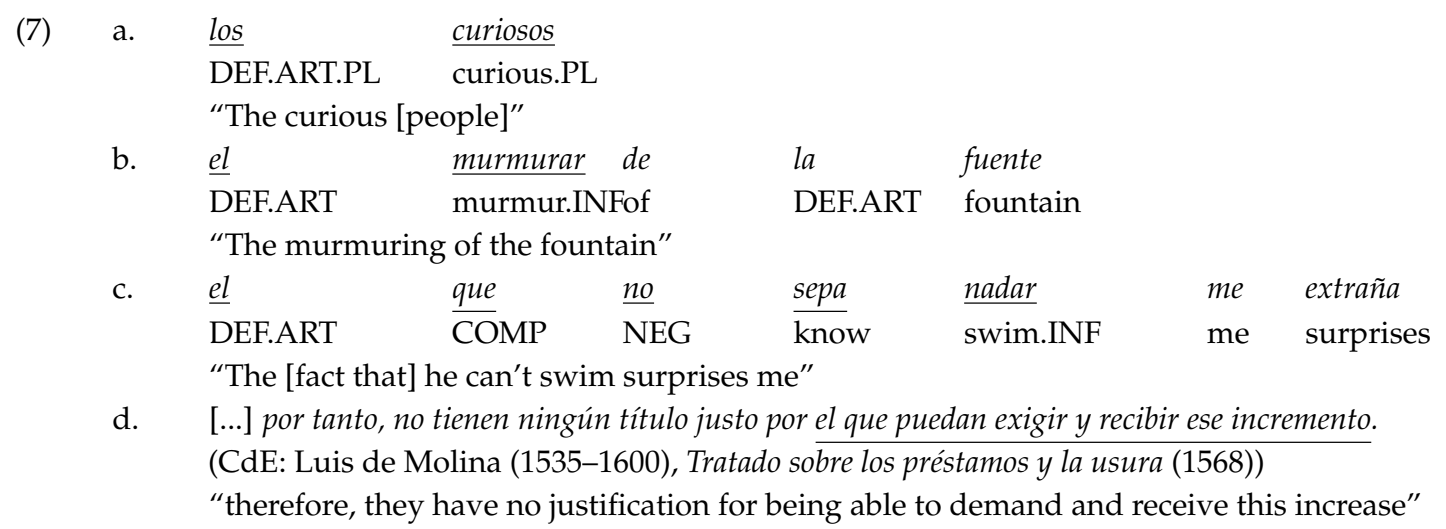

Finally, it should be noted that there is apparently a good deal of idiosyncrasy (at least from a comparative point of view: see Butt and Benjamin 2013, pp. 28-29) in the subsequent use of the definite article in modern Castilian, especially in prepositional phrases: consider, for example, the lack of parallelism between en la práctica "in practice" but en Ø teoria "in theory" and the apparent semantic contrast between en la cama y en Ø cama "in bed" (the latter is often said to imply illness).

Similarly, many uses of the definite article in modern Castilian that depend on particular syntactic contexts are also essentially idiosyncratic and liable to variation. Such idiosyncrasy can be observed with names of languages (habla Ø francés "(s)he speaks French" but habla bien el francés "(s)he speaks French well"), days of the week (a partir del domingo "from Sunday" but hoy es $\varnothing$ domingo "today is

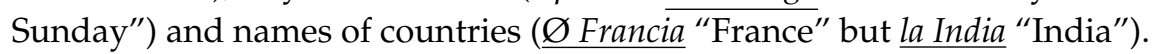

\subsubsection{The Indefinite Article}

The history of the indefinite article is fundamentally different from that of the definite article, since, while Lat. unus "one" underwent a significant expansion of functions, it never lost its numerical value: it is therefore inappropriate to speak of exaptation in this case, and its extension can be considered a case of adfunctionalization pure and simple. Until the 14th century, it maintained a specific and referential function, which was in accordance with its value as a numeral. It was only in the 15th century that the derivative of unus began to be used to signal new information that did not necessarily have a specific reference. In Golden Age Spanish, its extension to what is sometimes called (Garachana Camarero 2009, p. 401) a "metaphorical" value can be observed (8a), which included use with proper nouns (8b): in Table 3, as a simple but eloquent indication of this development, I give the figures derived from the CdE for the string es un $(a) \mathrm{N}$.

(8) a. Él es un ángel en la tierra, cierto, y vive entre nosotros de manera, como en las soledades del desierto (CdE: Miguel de Cervantes Saavedra (1547-1616), El rufián dichoso)

"He is an angel on earth, for sure, and lives amongst us as in the solitude of the desert"

b. Fijaos qué fuerza tiene la razón que, después de conocerla, sois un Cicerón o un San Pablo. (CdE: Jerónimo Jiménez de Urrea (1510-1574), Diálogo de la verdadera honra militar (1542))

"Consider what force reason has, for after becoming aware of it, you are a Cicero or a Saint Paul"

In addition, in the 16th century, the indefinite article extended to many of the contexts in which the definite article could already be used: it appears with unique reference entities (again with a "metaphorical" meaning (9a)), and as a nominalizer with infinitives and adjectives (9b-c). 
(9) a. su hermosura y gracias extremadas son hoy en día un sol que alumbra el mundo (CdE: Jorge de Montemayor (1520-1561), Los siete libros de la Diana, 1540)

"Her beauty and extreme graces are today a sun which gives light to the world"

b. Si restituir es un volver cuanto se tomó y dañó [...] (CdE: Tomás de Mercado (?-1575), Summa de tratos y contratos, 1545)

"If making restitution is (a) giving back of what was taken and damaged [...]"

c. $\quad$ un triste que siempre llora (CdE: José de Valdivielso (1560-1638), La serrana de Plasencia, 1599) "a sad person who is always crying"

Indicative statistics are difficult to provide, however: in particular, it did not prove practical to isolate instances of $u n(a)$ followed by an adjective without an accompanying noun. Table 4 gives the figures for the string $u n$ followed by an infinitive: while these inevitably include some lexicalized infinitives, the general direction of change is very clear.

Table 3. The string es un(a) $\mathrm{N}$ in CdE (raw figures and frequency per million words).

\begin{tabular}{|c|c|}
\hline & es un $(a) \mathrm{N}$ \\
\hline $1200 \mathrm{~s}$ & $90(13.40)$ \\
\hline $1300 \mathrm{~s}$ & $10(3.75)$ \\
\hline $1400 \mathrm{~s}$ & $61(7.47)$ \\
\hline $1500 \mathrm{~s}$ & $1936(113.65)$ \\
\hline $1600 \mathrm{~s}$ & $1649(133.54)$ \\
\hline $1700 \mathrm{~s}$ & $2526(257.32)$ \\
\hline $1800 \mathrm{~s}$ & $7665(397.21)$ \\
\hline $1900 \mathrm{~s}$ & $17,458(764.96)$ \\
\hline
\end{tabular}

Table 4. $u n$ + infinitive in CdE (raw figures and frequency per million words).

\begin{tabular}{|r|r|}
\hline & $u n+$ infinitive \\
\hline $1200 \mathrm{~s}$ & $11(1.64)$ \\
\hline $1300 \mathrm{~s}$ & $2(0.75)$ \\
\hline $1400 \mathrm{~s}$ & $15(1.84)$ \\
\hline $1500 \mathrm{~s}$ & $240(14.09)$ \\
\hline $1600 \mathrm{~s}$ & $98(7.94)$ \\
\hline $1700 \mathrm{~s}$ & $46(4.69)$ \\
\hline $1800 \mathrm{~s}$ & $183(9.48)$ \\
\hline $1900 \mathrm{~s}$ & $260(11.39$ \\
\hline
\end{tabular}

What is most striking in the evolution of the indefinite article, partly because it confirms its independence from its original numerical value and partly because it is a particularly prominent feature of Castilian (though the phenomenon is attested both formerly and currently in other Romance varieties, see Carlier (2001, pp. 81-84) for Old French, Ledgeway (2011, p. 410) and Vincent (2017)), is the appearance of the plural unos/as, which represents another important stage in the capitalization of unus, and, indeed, in its grammaticalization as an article. Table 5 shows a veritable explosion of this plural in the 16th century, although its modern use appears to be attested as early as the 13th century (10a). The majority of examples prior to the 16th century, however, seem to be of unos/as $\mathrm{N}$ in opposition with otros/as $\mathrm{N}(10 \mathrm{~b})$; unos/as could also appear with the definite article, especially if it marked anaphoric reference (10c). 
Table 5. Appearance of unos/unas $\mathrm{N}$ in CdE (raw figures).

\begin{tabular}{|c|c|c|c|}
\hline & unos/unas $\mathrm{N}+$ & algunos/as $\mathrm{N}+$ & unos/unas $\mathrm{N}$ as $\%$ of total \\
\hline $1200 \mathrm{~s}$ & 326 & 1045 & $23.78 \%$ \\
\hline $1300 \mathrm{~s}$ & 16 & 626 & $2.49 \%$ \\
\hline $1400 s$ & 85 & 4119 & $2.02 \%$ \\
\hline $1500 \mathrm{~s}$ & 4916 & 8984 & $35.37 \%$ \\
\hline $1600 \mathrm{~s}$ & 2875 & 4815 & $37.39 \%$ \\
\hline $1700 \mathrm{~s}$ & 2213 & 5944 & $27.13 \%$ \\
\hline $1800 \mathrm{~s}$ & 4002 & 7566 & $34.60 \%$ \\
\hline 1900s & 6773 & 8568 & $44.15 \%$ \\
\hline
\end{tabular}

(10) a. Esse anno priso Autuman Rey de los Alaraues unas tierras que son llamadas por sus nombres [...] (CdE: Alfonso X, Estoria de España I, 13th cent.)

"That year Autuman King of the Arabs captured lands which are called [...]"

b. Unas tierras dan vino, en otras dan dineros (CdE: Gonzalo de Berceo, La vida de San Millán de la Cogolla, 466a, 13th cent.).

"Some lands yield wine, in others they give money"

c. Et los unos panes auien nombre sacerdotales./Los otros panes leuiticos. (CdE: Alfonso X, General estoria $I, 13$ th cent.).

"And one kind of bread was called priestly [and] the other kind of bread [was called] Levitical."

Table 5 also gives the figures for algunos/as $\mathrm{N}$ and the percentage of unos/unas $\mathrm{N}$ of the combined total of unos/unas $\mathrm{N}$ and algunos/algunas $\mathrm{N}$, from which the more or less constant effect of unos/unas $\mathrm{N}$ and its steady competition with algunos/algunas from the 16th century onwards can be seen.

\subsection{Representation of Covert Distinctions}

Having established the general lines of the expansion of the functions of the Castilian articles, we now consider the second characteristic of capitalization, the extent to which the introduction of the articles made overt distinctions which were previously covert.

The most obvious distinction is that between the anaphoric value of the definite article referring to an established discourse topic and the non-anaphoric value of the indefinite article introducing a new topic, which is, moreover, the most fundamental and longest established general functional contrast between the two articles. A clear early example is (11), where una niña is used to mark the first mention of the little girl in the discourse; once introduced, she is then referred to anaphorically as la niña:

\footnotetext{
Una niña de nuef años a oio se parava [...]

Esto la niña dixo e tornós' para su casa (Poema de Mio Cid, 40; 49, 13th cent.?)

"A little nine-year-old girl appeared before their eyes [...]

This is what the girl said, and [then] she went back to her home."
}

This does not mean to say, of course, that in the absence of articles Latin had no recourse for expressing anaphoricity in the case of necessity: we have seen that this was one of the functions of the Latin demonstratives, and that the "weak" demonstrative IS, for which in a sense ille was a substitute (see André and Fruyt 2012), also discharged this function. Anaphoricity is also dependent on word order: Lyons (1968, p. 392) called attention to the fact that the topic of a sentence is usually "definite", whether or not such definiteness is explicitly marked. He commented on the Latin sentences in (12) that in (12a) and (12b) the topic is determined by word order, so that the expected value of liber "book" in (12a), where it is in final position, is that it is not the topic (and non-anaphoric), while in (12b), where it occurs initially, it is the topic (and anaphoric). 


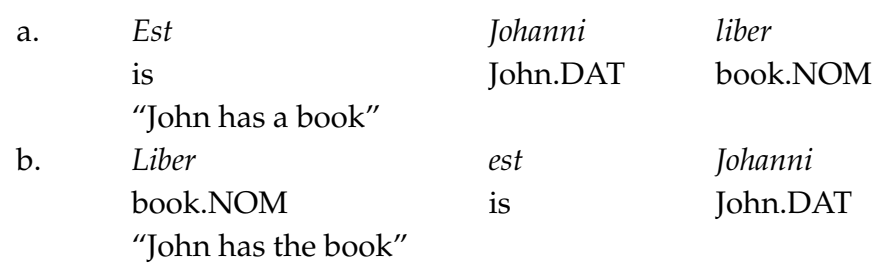

(See also (Bauer 2009) on the relation between case and definiteness in Latin.) The article in fact very often seems to be a superfluous element, since it expresses functions that can very well be deduced from the discourse context. It is important to stress this, because within Romance linguistics there is a long tradition that associates the development of the definite article with the supposed typological passage from synthesis (Latin) to analysis (the Romance languages). Alvarez Martínez (1986, p. 18), quoting Abel (1971, p. 1), went so far as to say that the creation of the article is a central problem of Romance linguistics and indeed of general linguistics because it allows synthetic languages to be distinguished from analytic languages. Harris $(1978$, p. 70$)$ similarly opined that the evolution of the articles as markers of specificity is "in accordance with the general tendency towards explicitness and towards preposed category marking". Some scholars have accordingly been tempted to wonder how Latin functioned without an article: Meillet and Vendryes $(1966$, p. 591) said that the absence of the article makes itself felt ["se fait sentir"] in cases such as (13):

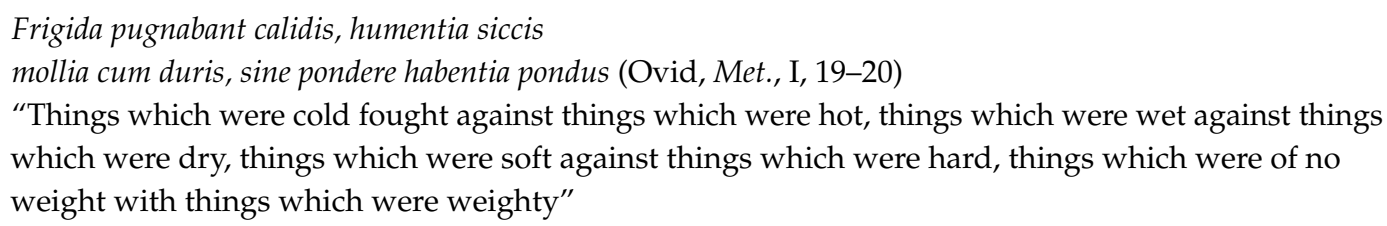

However, in reality, what, if anything, was lacking in Latin were adjectives corresponding to the notions of sine pondere and habentia pondus and there is actually no difficulty at all in understanding what Ovid wanted to express. As Pinkster points out:

In spite of the absence of the definite and indefinite article, in the Latin texts it is in a very large number of cases clear whether an NP is definite or indefinite. (Pinkster 1990, pp. 93-94)

Pinkster mentioned unique reference entities, proper nouns, inalienable possession and the anaphoric reference of a second mention noun as cases in which the presence of an article is in fact superfluous, and in similar vein Chesterman (1991, p. 4) quoted the opinion of Gardiner (1932, p. 47) according to whom the article "is mere useless ballast".

\subsection{The Creation of New Expressive Possibilities}

The view that the article is a redundant category is worth pursuing a little further in relation to capitalization, since it often seems that capitalization is concerned with the creation of categories that from a functional point of view can to a certain extent be regarded as superfluous. In the cases of capitalization I have already analyzed (the rise of the copula estar, the reflexive as an exponent of the middle voice, and the introduction of a neo-neuter article), the distinctions which these developments appear to make explicit, and the new expressive possibilities they create, are very far from being universal, and this is precisely why they become distinctive features of Castilian, giving it an individual "cut". However, while a similar case might be made in a broad comparison between languages with articles and languages without articles, a definite article deriving from a demonstrative has been perceived as a common enough feature for Greenberg (1978) to establish his "cycle of definiteness", and even for this evolutionary pathway to be regarded by some as universal (Faingold 2003, p. 39). It seems clear that Castilian is broadly at Stage II of the Greenberg cycle (the article is largely grammaticalized and determined by the syntactic context, but there is some residual contrast between the presence and absence of the article) and has not yet reached Stage III (the article is merely a nominal marker with no distinctive function). While, then, there is a degree of redundancy in the article at Stage II, there is still 
opportunity for its exploitation to create new expressive possibilities, as I show below. It is precisely at this point that the differences between closely related languages emerge: Harris (1980, p. 82) concluded that French is also at Stage II of the Greenberg cycle; however, French has clearly moved further than Castilian towards Stage III, and a number of the new expressive possibilities identified in this section for Castilian are simply unavailable to French.

We turn, therefore, to the third characteristic of capitalization: that it appears to allow new expressive possibilities or more "felicitous" or economical modes of expression. We should again remember that, as far as the articles are concerned, we do not have a binary distinction between definite and indefinite, but a tripartite distinction among definite, indefinite and lack of determination or zero article, a possibility that has always been available in Castilian (cf. Kabatek 2012, p. 85).

The area in which one can put the most effective argument for the introduction of new expressive possibilities in Castilian by comparison with Latin and indeed by comparison with other languages is not in the opposition between definite and indefinite article as such but in the oppositions definite article/zero article and indefinite article/zero article, at a fairly advanced stage of the development of the articles. For example, in the complements of the copular verb ser "to be", the absence of the article usually denotes literal membership of a class or category (14a), while the presence of the indefinite article implies a value judgement (the so-called "metaphorical" value of the indefinite article) (14b). These sentences are difficult to gloss in English except by lengthy paraphrase, since in English the indefinite article is always obligatorily present ("Juan is a politician"); to render the full sense of (14b) a different verb must be used ("John behaves like a politician") or an adjective introduced ("John is a real politician"). While (14a) is an objective statement, (14b) is a value-judgement, i.e. (14b) is not literally true, and (14b) does not imply (14a).

(14) a. Juan es Ø político

b. Juan es un politico

Another contrastive context for the indefinite and zero articles is in the complements of verbs such as tener "to have" and comprar "to buy": here the presence of the indefinite article (15a) is unmarked because it represents the normal pragmatic expectation ("Do you know that our friend Juan has bought a car?"). The implication of (15b), on the other hand, is once again more difficult to render in English. Alonso (1933, p. 198) paraphrased it by saying that it is the category to which the object bought by Juan belongs that is at the forefront of the speaker's mind, and represents a change in status; for this, an appropriate English gloss is "Do you know that John has become a car owner?"

(15) a. ¿Sabes que nuestro amigo Juan ha comprado un automóvil? Alonso (1933, p. 198)

b. ¿ ¿Sabes que nuestro amigo Juan ha comprado Ø automóvil?

Examples similar to (15b) can be identified from quite early in the Castilian textual record: Company Concepción (1991, pp. 406-7) called attention to contrasts between the definite and zero articles such as those in (16). (16a), similar to (15a), has a straightforward objective reading; the only complication in giving an English gloss is that we should understand the sword (and, for that matter, the neck of the victim) as inalienably possessed. (16b), similar to (15b), has a different nuance that is not fully expressed by the simple English gloss given: it refers to the moment at which the Cid became a knight and hence implies his symbolic taking up of his sword, a change in his status; it is a formulaic expression in this epic.

(16) a. dio muy grant ferida con el espada en el pescuezo (Primera Crónica General, 118a7, 13th cent.)

"He dealt a very great blow with [his] sword on [his] neck"

b. $\quad$ en buen ora cinxiestes $\varnothing$ espada (Poema de Mio Cid, 41, 13th cent.?)

"In a good hour you girded on [your] sword"

A final area in which we may speak of the creation of a new expressive possibility is in the opposition between the plural indefinite article unos/unas and the zero article. Unos/unas individualizes nouns which appear in the plural: unas gafas denotes a single entity ("a pair of spectacles"), unas 
vacaciones a single instance ("a holiday") (De Bruyne 1995, p. 62): such a value is also attested in Old and Middle French and in Occitan (Ledgeway 2011, p. 410). Butt and Benjamin (2013, p. 47) noted that unos/unas "can add a modest note", perhaps because it implies a limited quantity, not just the vague "some", as in (17).

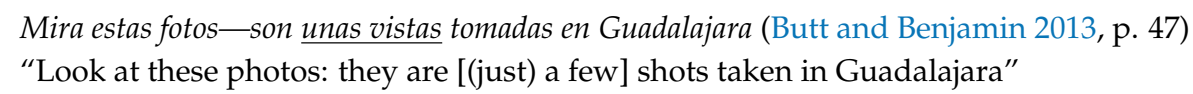

With figures, unos/unas indicates an approximate quantity:

$$
\begin{aligned}
& \text { a. } \quad \frac{\varnothing \text { doscientas personas }}{\text { "two hundred people [exactly]" }} \\
& \text { b. } \frac{\text { unas doscientas personas }}{\text { "about two hundred people" }}
\end{aligned}
$$

with percentages there is a similar opposition between the definite and indefinite articles:

(19) a. el $20 \%$ de los alumnos

"20\% [exactly] of the students"

b. un $20 \%$ de los alumnos

"[approximately] 20\% of the students"

\subsection{Impact on the Grammatical System}

Although within the grammatical tradition articles are usually isolated as a category apart, it is clear that they are part of an extensive system of nominal premodifiers, or determiners, with which they are closely related. The articles, then, could not in themselves have been a motivating factor in the creation of the class of determiners; it is more probable that they became part of an already existing system, even though they reinforced and extended it; this system would continue to extend progressively with the introduction of ever more elements. As Tables 6-8 show, "introductory" cierto "(a) certain", indefinite algún "some" and anaphoric dicho "the aforementioned" have been embedded in the language for a long period, while introductory determinado "(a) certain", indefinite varios "several" and anaphoric mencionado, referido and citado "the aforementioned" are of more recent date (the English glosses give simple semantic equivalences; they are not necessarily equivalent in register or frequency of occurrence). Once again, such figures are not very rigorous, but they do indicate the general lines of development.

Table 6. "Introductory" determiners in Castilian in CdE (raw figures).

\begin{tabular}{|r|r|r|}
\hline & cierto/a/os/as $\mathrm{N}$ & determinada/os/as $\mathrm{N}$ \\
\hline $1200 \mathrm{~s}$ & 303 & 0 \\
\hline $1300 \mathrm{~s}$ & 289 & 0 \\
\hline $1400 \mathrm{~s}$ & 1384 & 12 \\
\hline $1500 \mathrm{~s}$ & 3516 & 48 \\
\hline $1600 \mathrm{~s}$ & 1068 & 14 \\
\hline $1700 \mathrm{~s}$ & 1658 & 189 \\
\hline $1800 \mathrm{~s}$ & 6247 & 269 \\
\hline $1900 \mathrm{~s}$ & 5138 & 1062 \\
\hline
\end{tabular}

† sample of 1000 nouns.

The interaction of the articles with other determiners is indeed one of the most interesting aspects of the history of the Romance article from the point of view of capitalization, since it creates even more expressive possibilities within this wider system, as I show below. 
Table 7. Indefinite determiners in Castilian in CdE (raw figures).

\begin{tabular}{|r|r|r|r|}
\hline & algún/alguna $\mathrm{N}$ & algunos/algunas $\mathrm{N}$ & varios/as $\mathrm{N}$ \\
\hline $1200 \mathrm{~s}$ & 4303 & 1045 & 4 \\
\hline $1300 \mathrm{~s}$ & 1097 & 626 & 7 \\
\hline $1400 \mathrm{~s}$ & 4348 & 4119 & 30 \\
\hline $1500 \mathrm{~s}$ & 10,261 & 8984 & 844 \\
\hline $1600 \mathrm{~s}$ & 5555 & 4815 & 931 \\
\hline $1700 \mathrm{~s}$ & 7399 & 5944 & 3277 \\
\hline $1800 \mathrm{~s}$ & 7999 & 7566 & 2697 \\
\hline $1900 \mathrm{~s}$ & 6523 & 8568 & 6702 \\
\hline \multicolumn{4}{|c|}{ t sample of 1000 nouns. } \\
\hline
\end{tabular}

Table 8. Anaphoric determiners in Castilian in CdE (raw figures).

\begin{tabular}{|c|c|c|c|c|}
\hline & dicha/os/as † & citada/os/as $\mathrm{N}$ & referida/os/as $\mathrm{N}$ & mencionada/os/as $\mathrm{N}$ \\
\hline $1200 \mathrm{~s}$ & 156 & 0 & 0 & 0 \\
\hline $1300 \mathrm{~s}$ & 247 & 0 & 0 & 0 \\
\hline $1400 \mathrm{~s}$ & 4587 & 0 & 0 & 0 \\
\hline $1500 \mathrm{~s}$ & 3459 & 4 & 24 & 2 \\
\hline $1600 \mathrm{~s}$ & 834 & 2 & 94 & 0 \\
\hline $1700 \mathrm{~s}$ & 2922 & 190 & 149 & 72 \\
\hline $1800 \mathrm{~s}$ & 2411 & 166 & 109 & 92 \\
\hline $1900 \mathrm{~s}$ & 1013 & 114 & 44 & 66 \\
\hline
\end{tabular}

\subsubsection{With Demonstratives}

The fundamental impossibility of combining an article with a demonstrative in both Spanish and English ( ${ }^{*}$ el este libro/*the this book; *un este libro/*a this book) is easily understood. The definite article and the demonstrative duplicate similar anaphoric and deictic functions, while the indefinite article and the demonstrative are incompatible in terms of these functions. Nonetheless, in relatively recent times, the sequence $e l+\mathrm{N}+$ demonstrative has been exploited in Spanish to express a new ironical nuance. It is difficult to fix the origins of this possibility with any certainty, since it seems that the construction originates in the informal spoken language which is not represented with any regularity in the written texts on which the corpora are based, but examples can be found in CdE for the 19th century: in (20) I give one of these with a deliberately extended context so that its meaning can be more fully appreciated:

(20) Y esto no quiere decir, claro está, que se deba abandonar el lenguaje y el estilo y escribir con desatino. Pero de ello a convertirse en esclavo de un molde, vaya mucha diferencia. En mi sentir, el escollo este del molde viene, sobre todo, del deseo de originalidad. (CdE: Amado Nervo (1870-1919), La lengua y la literatura (1894)).

"And clearly this does not mean to say that language and style should be abandoned and that one should write loosely. But there is a big difference between doing that and becoming a slave to a particular model. In my view, this [terrible] obstacle of the model comes chiefly from the desire for originality."

[The author is criticizing the idea of a model in writing.]

\subsubsection{With Possessives}

In Old Castilian, both articles could combine with the possessive. As can be seen in Tables 9-11, $e l+\mathrm{POSS}+\mathrm{N}$ has always been a minority variant, with no appreciable semantic difference from $\varnothing+$ POSS $+\mathrm{N}$; but $u n+$ POSS $+\mathrm{N}(21 \mathrm{a})$, even if it did not exactly constitute a new expressive possibility, is quite different in meaning from $(\mathrm{el})+\mathrm{POSS}+\mathrm{N}$, and was yet another more economical ("felicitous") 
means of expressing the notion of "one of" + POSS N. From the 16th century onwards, this construction is replaced increasingly by $u n+N+$ POSS (21b), and another possibility for expressing the same notion, though a minority variant, as can be seen in Table 11, is the analytical formula uno/a de + POSS $+\mathrm{N}(21 \mathrm{c})$.

Table 9. $\varnothing+$ POSS $+\mathrm{N}$ in CdE (raw occurrences)

\begin{tabular}{|r|r|}
\hline & (Ø) POSS N + +† \\
\hline $1200 \mathrm{~s}$ & 44,388 \\
\hline $1300 \mathrm{~s}$ & 16,471 \\
\hline $1400 \mathrm{~s}$ & 42,865 \\
\hline $1500 \mathrm{~s}$ & 158,796 \\
\hline $1600 \mathrm{~s}$ & 150,815 \\
\hline $1700 \mathrm{~s}$ & 71,314 \\
\hline $1800 \mathrm{~s}$ & 189,395 \\
\hline $1900 \mathrm{~s}$ & 95,535 \\
\hline
\end{tabular}

† Based on a sample of 1000 nouns. + It would be very difficult to calculate the frequency of $\varnothing+$ POSS $+N$, since it is impossible to isolate just this sequence in a search. The figure given here is for the raw occurrences of POSS $+\mathrm{N}$ and so includes all instances of preposed determiners; even so, it is clear that $\varnothing+$ POSS $+\mathrm{N}$ has always been the majority variant, as may be verified by subtracting from these figures the total of the figures in the tables for definite and indefinite article and demonstrative + POSS.).

Table 10. Definite article + POSS $+\mathrm{N}$ in CdE (raw occurrences).

\begin{tabular}{|l|r|r|}
\hline & el/la POSS N + & los/las POSS N + \\
\hline $1200 s$ & 2360 & 2077 \\
\hline $1300 s$ & 806 & 838 \\
\hline $1400 \mathrm{~s}$ & 1186 & 1502 \\
\hline $1500 \mathrm{~s}$ & 285 & 293 \\
\hline $1600 \mathrm{~s}$ & 42 & 35 \\
\hline $1700 \mathrm{~s}$ & 96 & 692 \\
\hline $1800 \mathrm{~s}$ & 55 & 56 \\
\hline $1900 \mathrm{~s}$ & 9 & 7 \\
\hline
\end{tabular}

t Based on a sample of 1000 nouns.

Table 11. Indefinite article + POSS $+\mathrm{N}$ in CdE (raw occurrences).

\begin{tabular}{|c|c|c|c|c|c|c|}
\hline & $\begin{array}{l}\text { un/una } \\
\text { POSS N }\end{array}$ & $\begin{array}{l}\text { un/una } \\
\text { N POSS }\end{array}$ & $\begin{array}{l}\text { uno/una de } \\
\text { POSS Nt }\end{array}$ & $\begin{array}{l}\text { unos/unas } \\
\text { POSS N }\end{array}$ & $\begin{array}{l}\text { unos/unas } \\
\text { N POSS }\end{array}$ & $\begin{array}{l}\text { unos/unas de } \\
\text { POSS N }\end{array}$ \\
\hline $1200 s$ & 74 & 5 & 18 & 8 & 0 & 7 \\
\hline $1300 \mathrm{~s}$ & 3 & 1 & 7 & 1 & 0 & 0 \\
\hline $1400 \mathrm{~s}$ & 15 & 11 & 6 & 0 & 1 & 0 \\
\hline $1500 \mathrm{~s}$ & 349 & 965 & 230 & 7 & 24 & 2 \\
\hline $1600 \mathrm{~s}$ & 88 & 772 & 174 & 7 & 28 & 0 \\
\hline $1700 \mathrm{~s}$ & 27 & 364 & 216 & 6 & 9 & 0 \\
\hline $1800 \mathrm{~s}$ & 100 & 581 & 799 & 6 & 15 & 7 \\
\hline $1900 \mathrm{~s}$ & 13 & 403 & 1094 & 0 & 15 & 5 \\
\hline
\end{tabular}

(21) a. tiene preso un mi hermano (CdE: Diego Ortúñez de Calahorra, Espejo de príncipes y cavalleros. Libro II (s.XVI))

"he holds one of my brothers prisoner"

b. Por gran ventura hallé en ella tres hijos de un hermano mío, de quien yo no había sabido en muchos años (CdE: Pedro Fernandes de Queiros (1565-1615), Historia del descubrimiento de las regiones austriales (1590))

"By good fortune I found there three children of one of my brothers, of whom I had heard nothing for many years."

c. $\quad y$ topó en el camino uno de sus compañeros, que también iba huyendo (CdE: José de Acosta (1539-1600), Cartas (1570)).

"and he met one of his companions on the road, who was also fleeing" 
Demonstratives and quantifiers are also used in the same sense and follow a similar evolutionary trajectory, although at different paces (statistics for algún and (aqu)este are given in Tables 12 and 13).

Table 12. Algún, etc. + POSS $+\mathrm{N}$ in CdE (raw occurrences).

\begin{tabular}{|r|r|r|}
\hline & algún, etc., POSS N & algún, etc. N POSS \\
\hline $1200 s$ & 53 & 19 \\
\hline $1300 s$ & 10 & 1 \\
\hline $1400 s$ & 30 & 18 \\
\hline $1500 s$ & 26 & 116 \\
\hline $1600 s$ & 15 & 92 \\
\hline $1700 s$ & 16 & 98 \\
\hline $1800 s$ & 10 & 51 \\
\hline $1900 s$ & 4 & 17 \\
\hline
\end{tabular}

Table 13. Demonstrative + POSS $+\mathrm{N}$ in CdE (raw occurrences).

\begin{tabular}{|r|r|r|}
\hline & (aqu)este, etc. POSS N † & (aqu)este, etc. N POSS \\
\hline $1200 s$ & 383 & 7 \\
\hline $1300 s$ & 126 & 2 \\
\hline $1400 s$ & 292 & 6 \\
\hline $1500 s$ & 889 & 144 \\
\hline $1600 s$ & 256 & 99 \\
\hline $1700 s$ & 268 & 78 \\
\hline $1800 s$ & 246 & 123 \\
\hline $1900 s$ & 31 & 50 \\
\hline
\end{tabular}

+ Based on a sample of 1000 nouns.

\subsubsection{With tal}

Another determiner that enters into a relationship with the articles is tal. This is a very interesting case, since, although combination with the article is never a majority variant, the presence of the article creates a functional opposition, which again may be the result of capitalization. El/la tal $+\mathrm{N}$, which was fairly frequent until the 17 th century, is always anaphoric (22a) and is a near synonym of the demonstrative este/esta; el/la tal, with no noun, is also used pronominally (22b). Up until the 18th century, un/una tal $\mathrm{N}$ had the corresponding consecutive sense of a degree (22c) or comparison ("of this kind") (22d), but it then acquires a secondary meaning of "a certain N", especially with proper nouns, which from this century comes to be predominant and is its present-day sense (22e). In this way, tal with an indefinite article shows a certain independence of tal with the definite article, and it cannot be said that after this century their evolution is parallel. In Table 14, the statistics obtained from $\mathrm{CdE}$ for the raw el/la tal $+\mathrm{N}$, un/una tal $+\mathrm{N}$ are given, together with an estimated figure for $\varnothing+t a l+\mathrm{N}$, calculated on the basis of the total number of occurrences of tal $\mathrm{N}$ minus those of tal $\mathrm{N}$ preceded by an article: the figures for $e l / l a+t a l+\mathrm{N}, u n / u n a+t a l+\mathrm{N}$ therefore cannot be exact, but, even so, the figures are highly suggestive.

Table 14. tal in CdE (raw occurrences).

\begin{tabular}{|r|r|r|r|}
\hline & el/la tal $\mathrm{N}+$ & un/una tal $\mathrm{N}$ & $\varnothing$ tal $\mathrm{N}+$ \\
\hline $1200 \mathrm{~s}$ & 33 & 3 & 4358 \\
\hline $1300 \mathrm{~s}$ & 54 & 3 & 1784 \\
\hline $1400 \mathrm{~s}$ & 1159 & 2 & 5146 \\
\hline $1500 \mathrm{~s}$ & 568 & 219 & 10,090 \\
\hline $1600 \mathrm{~s}$ & 201 & 21 & 6025 \\
\hline $1700 \mathrm{~s}$ & 264 & 55 & 4540 \\
\hline $1800 \mathrm{~s}$ & 352 & 43 & 9719 \\
\hline $1900 \mathrm{~s}$ & 26 & 22 & 4514 \\
\hline
\end{tabular}

t based on a sample of 1000 sentences. 
(22) a. donde había sido corregidor sin haber aún sacado a su mujer del distrito de su corregimiento por haber poco tiempo que había dejado el tal oficio (CdE: Pedro Mariño de Lobera, Crónica del Reino de Chile, 16th cent.)

"where he had been corregidor, without yet having brought his wife from the district of his jurisdiction because of the short space of time which had passed since he had left this office"

b. $\quad y$ si el tal, como atrás dixe, había subido a ser señor por sus hazañosos hechos, por extenso contaban sus valentías y cómo de grado en grado había subido y tenido tanta fortuna, que meresciese en su muerte ser tan honrado (CdE: Francisco Cervantes de Salazar (1514-1575), Crónica de la Nueva España (1544)).

"And if such a person, as I said earlier, had risen to the nobility through his glorious deeds, they recounted his brave acts and how he had risen rank by rank and acquired such a great fortune that he deserved to be so honoured on his death."

c. $\quad Y$ en llegando le da un tal golpe de través encima el yelmo que muy lexos de allí le hizo saltar muchas centellas (CdE: Diego Ortúñez de Calahorra, Espejo de príncipes y cavalleros. Libro III, S.XVI).

"And when he reached [him] he gave him such a sideways blow on his helmet that he made sparks fly a great distance"

d. No pudo Numisio resistir a una tal confabulación de voluntades, y convino en trasladarse a Roma con su mujer y su cuñado (CdE: Joaquín Costa (1846-1911), Último día del paganismo y primero de lo mismo, 1878).

"Numisio could not resist such a conspiracy of wills, and he agreed to move to Rome with his wife and brother-in-law."

e. Refiere que el primero que procuró averiguarla por este método fue un tal Felipe Guillén, boticario de Sevilla (CdE: Martín Fernández de Navarrete (1756-1844), Disertación sobre la historia de la nautica y de las ciencias matemáticas que han contribuido a sus progresos entre los españoles, 1800). "It reports that the first person who tried to verify it by this method was a certain Felipe Guillén, a pharmacist in Seville."

\section{Conclusions}

The extension of the functions of the Castilian articles traced in outline here exemplify capitalization or serial adfunctionalization. This is particularly clear in the case of the indefinite article, which still includes its original value as a numeral. The definite article, it is true, loses some of the deictic force of the demonstrative from which it derives (and accordingly contrasts functionally with the new Romance demonstratives), but it continues another of the fundamental functions of the demonstrative, that of anaphoric reference. In the course of their history to date, both articles have developed a range of additional, though related, functions. The process is therefore comparable to that undergone by estar and the reflexive (non-exaptive) and to the neo-neuter lo (exaptive).

As regards the other properties that I have identified as typical of capitalization, I have demonstrated that the articles make overt some distinctions that were previously covert, chiefly and most importantly the distinction between anaphoricity or "definiteness" and non-anaphoricity or "indefiniteness". At the same time, it is also clear that, in many, if not the majority, of their functions, the articles are a superfluous element whose value depends on the discourse context or pragmatic conditions. The possible ambiguity of the definite article between anaphoricity and genericness in fact does not present difficulties of interpretation.

It is also clear that the expansion of the articles brought about the creation of new expressive possibilities, mainly the opposition between the indefinite article and the zero article.

The effect that the articles have had on the grammatical system is more difficult to evaluate. The articles play their part in the emergence in Romance of a DP (Determiner Phrase) structure (Ledgeway 2011, p. 409); it does not seem that the articles created the system of determiners, however, but rather that they broadened it and opened the way for the incorporation (and maybe also coining) of other elements, such as the more explicit anaphoric expressions of modern Castilian. It is also possible that the dependence of the development of the indefinite article on that of the definite article can be overestimated, since from the 16th century the indefinite article has shown a marked originality by 
comparison with the definite. It is perhaps in the interaction of the articles with other determiners that we see the clearest impact of a structural kind.

The history of the articles is therefore a topic of great interest for a theory of adfunctionalization, despite the many challenges it also poses.

Funding: This research received no external funding

Conflicts of Interest: The author declares no conflict of interest.

\section{References}

Abel, Fritz. 1971. L'adjectif démonstratif dans la langue de la Bible latine. Etude sur la formation des systèmes déictiques et de l'article défini des langues romanes. (= Beihefte zur Zeitschrift für romanische Philologie, 125.). Tübingen: Niemeyer.

Alonso, Amado. 1933. Estilística y gramática del artículo en español. Volkstum und Kultur der Romanen 6: 189-209. Alvarez Martínez, María Ángeles. 1986. El artículo como entidad funcional en el español de hoy. Madrid: Gredos.

Álvarez Menéndez, Alfredo. 1970. Énfasis y transposición de oración a sustantivo. Revista Española de Lingüística 17: $347-70$.

André, Aurélie, and Michèle Fruyt. 2012. Le rôle de is dans le changements de l'endophore et de la déixis en latin. In Latin Vulgaire-Latin Tardif IX. Actes du IXè colloque international sur le latin vulgaire et tardif, Lyon, 2-6 Septembre 2009. Lyon: Maison de l'Orient et de la Méditéranée-Jean Pouilloux.

Badía Margarit, Antonio. 1951. Gramática histórica catalana. Barcelona: Noguer.

Bauer, Brigitte L. M. 2009. Strategies of definiteness in Latin: implications for early Indo-European. In Grammatical Change in Indo-European Languages. Papers Presented at the workshop on Indo-European Linguistics at the XVIIth International Conference on Historical Linguistics, Montreal. Amsterdam and Philadelphia: John Benjamins.

Butt, John, and Carmen Benjamin. 2013. A New Reference Grammar of Modern Spanish, 5th ed. London: Arnold.

Carlier, Anne. 2001. La genèse de l'article un. Langue française 130: 65-88. [CrossRef]

Chesterman, Andrew. 1991. On Definiteness. Cambridge: Cambridge University Press.

Company Concepción. 1991. La extensión del artículo en el español medieval. Romance Philology 44: 402-24.

Davies, Mark. 2002-2019. Corpus del Español: 100 Million Words, 1200s-1900s. Available online: http:/ /www. corpusdelespanol.org/hist-gen/ (accessed on 31 October 2017).

De Bruyne, Jacques. 1995. A Comprehensive Spanish Grammar, adapted with additional material by Christopher J. Pountain. Oxford: Blackwell.

Faingold, Eduardo D. 2003. The Development of Grammar in Spanish and the Romance Languages. Basingstoke: Palgrave Macmillan.

Garachana Camarero, Mar. 2009. La creación y generalización del artículo indefinido. In Sintaxis histórica de la lengua española. Segunda parte: La frase nominal. Edited by Company Concepción. México: Universidad Autónoma de México/Fondo de Cultura Económica, pp. 389-464.

Gardiner, Alan H. 1932. The Theory of Speech and Language. Oxford: Clarendon.

Greenberg, Joseph H. 1978. How does a language acquire gender markers? In Universals of Human Language. Stanford: Stanford University Press.

Gutiérrez Rexach, Javier. 1999. The structure and interpretation of Spanish degree-neuter constructions. Lingua 109: 35-63. [CrossRef]

Harris, Martin B. 1978. The Evolution of French Syntax: A Comparative Approach. London: Longman.

Harris, Martin B. 1980. The marking of definiteness: A diachronic perspective. In Papers from the Fourth International Conference on Historical Linguistics. Amsterdam and Philadelphia: John Benjamins.

Kabatek, Johannes. 2012. Nuevos rumbos en la sintaxis histórica. In Actas del IX Congreso Internacional de Historia de la Lengua Española. Santiago de Compostela: Meubook.

Lass, Roger. 1990. How to do things with junk: Exaptation in language evolution. Journal of Linguistics 26: 9-102. [CrossRef]

Ledgeway, Adam. 2011. Syntactic and Morphosyntactic Typology and Change. In The Cambridge History of the Romance Languages. Volume 1. Structures.. Edited by Martin Maiden, John Charles Smith and Adam Ledgeway. Cambridge: Cambridge University Press, pp. 382-471.

Lyons, John. 1968. Introduction to Theoretical Linguistics. Cambridge: Cambridge University Press. 
Meillet, Par A., and Joseph Vendryes. 1966. Traité de Grammaire Comparée des Langues Classiques, 4th ed. Paris: Champion.

Moreira Rodríguez, Antonia, and John Butt. 1996. "Se de matización" and the Semantics of Spanish Pronominal Verbs. London: Department of Spanish and Spanish-American Studies, King's College London.

Ortiz Ciscomani, Rosa María. 2009. La creación y generalización del artículo definido. In Sintaxis histórica de la lengua española. Segunda parte: La frase nominal. Edited by Company Concepción. México: Universidad Autónoma de México/Fondo de Cultura Económica, pp. 273-386.

Pinkster, Harm. 1990. Latin Syntax and Semantics. London and New York: Routledge.

Pountain, Christopher J. 2000a. “Capitalization". In Historical Linguistics 1995, Volume 1: General Issues and non-Germanic Languages. Edited by John Charles Smith and Delia Bentley. Amsterdam \& Philadelphia: John Benjamins, pp. 295-309.

Pountain, Christopher J. 2000b. Pragmatic Factors in the Evolution of the Romance Reflexive (with special reference to Spanish). Hispanic Research Journal 1: 5-25. [CrossRef]

Pountain, Christopher J. 2000c. "La supuesta ambigüedad del reflexivo español". In Actes du 22e Congrès de Linguistique et de Philologie Romanes, vol. VII, ed. Edited by Annick Englebert, Michel Pierrard, Laurence Rosier and Dan Van Raemdonck. Tübingen: Niemeyer, pp. 615-24.

Pountain, Christopher J. 2008. The Genius of Language. Public Lecture given at the University of Newcastle-upon-Tyne. Available online: http://webspace.qmul.ac.uk/cjpountain/genius.pdf (accessed on 31 October 2017).

Pountain, Christopher J. 2015. "Lo + adjetivo: por la exaptación a la capitalización”. In Actas del IX Congreso Internacional de Historia de la Lengua Española (Cádiz, 2012). Edited by José Marí García Martín, Teresa Bastardín Candón and Manuel Rivas Zancarrón. Madrid and Frankfurt: Iberoamericana/Vervuert, vol. I, pp. 1035-48. Sapir, Edward. 1921. Language: An Introduction to the Study of Speech. London: Hart-Davis.

Smith, John Charles. 2011. Change and Continuity in Form-Function Relationships. In The Cambridge History of the Romance Languages. Volume 1. Structures.. Edited by Martin Maiden, John Charles Smith and Adam Ledgeway. Cambridge: Cambridge University Press, pp. 268-317.

Vincent, Nigel. 2017. Determination and quantification. In Manual of Romance Morphosyntax and Syntax. Edited by Andreas Dufter and Elisabeth Stark. Berlin and Boston: Mouton de Gruyter, pp. 727-70.

Voltaire, Oeuvres Completes. 1879. Dictionnaire Philosophique. OEuvres Complètes. Paris: Garnier, vol. 19. First published 1757.

(C) 2019 by the author. Licensee MDPI, Basel, Switzerland. This article is an open access article distributed under the terms and conditions of the Creative Commons Attribution (CC BY) license (http:/ / creativecommons.org/licenses/by/4.0/). 